\title{
Rubella antibody levels in juvenile rheumatoid arthritis
}

\author{
CALVIN C. LINNEMANN, JR., JOSEPH E. LEVINSON, C. RALPH BUNCHER, AND \\ GILBERT M. SCHIFF \\ From the Special Treatment Center for Juvenile Arthritis, the Clinical Virology Section, \\ and Division of Epidemiology and Biostatistics, Departments of Medicine and Pediatrics, \\ University of Cincinnati Medical Center, Cincinnati, Ohio
}

\begin{abstract}
Linnemann, C. C., Jr., Levinson, J. E., Buncher, C. R., and Schiff, G. M. (1975). Annals of the Rheumatic Diseases, 34, 354-358. Rubella antibody levels in juvenile rheumatoid arthritis. Increased rubella antibody titres have been reported in patients with juvenile rheumatoid arthritis (JRA) and it has been suggested that rubella virus may be of importance in the aetiology or pathogenesis of the disease. In the present study, rubella and rubeola antibody titres in 85 patients with JRA were compared to age- and sex-matched controls. $41 \%$ of the patients did not have rubella antibody, but the geometric mean titre of those with JRA who had antibody was slightly higher than that of the controls with antibody (58.9 against $42.7 ; P<0.05$ ). The level of rubella antibody titre correlated with serum IgG levels. There was no difference in rubeola antibody titres between patients and controls, and rubeola antibody did not correlate with serum IgG. Fifteen JRA patients developed rubella antibody after rubella vaccine or natural disease. This did not result in unusually high antibody titres and was associated with a mild exacerbation of symptoms in only two patients. This study suggests that the slight increase in rubella antibody in JRA is a nonspecific manifestation of increased immunoglobulins.
\end{abstract}

The presence of increased viral antibodies may occasionally provide a clue to the aetiology of a disease, as was the case with subacute sclerosing panencephalitis (Connolly, Allen, Hurwitz, and Millar, 1967). However, in other diseases with raised viral antibodies, such as systemic lupus erythematosus (SLE) and multiple sclerosis, this has not contributed to an understanding of the causal agent (Phillips and Christian, 1970; Adams, 1967). In the case of SLE, the increase in viral antibodies is generally attributed to the hypergammaglobulinaemia which is associated with the disease (Phillips and Christian, 1973). Recently, reports by Ogra and Herd (1972) of increased rubella antibody titres in children with juvenile rheumatoid arthritis (JRA) in the absence of an increase in antibody to other common viruses suggested that rubella virus may have aetiological or pathological significance in this disease. Subsequently, Phillips, Lim, Parkman, and Hirshaut (1973) reported no significant increase in rubella, rubeola, parainfluenza type 1, or Epstein-Barr virus antibodies in 29 patients with definite JRA, although the antibody titres were slightly higher in the JRA group. The present study was undertaken to determine rubella antibody levels in a large series of patients with definite JRA and to evaluate the antibody response to rubella infection.

\section{Materials and methods}

STUDY POPULATION

Eighty-five patients with definite JRA who have been followed at the Special Treatment Center for Juvenile Arthritis at the University of Cincinnati Medical Center were included in the study. They were diagnosed in accordance with the criteria adopted by the American Rheumatism Association (Brewer, Bass, Cassidy, Duran, Fink, Jacobs, Markowitz, Reynolds, Schaller, Stillman, and Wallace, 1972). The patients included 62 females and 23 males. The mean age at onset of JRA was $7 \cdot 2$ years and mean age at the time of initial antibody testing was 10.3 years. There was acute febrile onset in $18 \%$ of the patients, pauciarticular onset in $54 \%$, and polyarticular onset in $28 \%$. The functional class was I for $47 \%$, II for $42 \%$, III for $9 \%$, and IV for $1 \%$. Serial blood specimens were 
collected from each patient during routine clinic visits between 1967 and 1972 and were used for a variety of laboratory tests, including rheumatoid factor, antinuclear antibody, and immunoelectrophoresis. The remaining serum was stored at $-20^{\circ} \mathrm{C}$. The earliest and the most recent blood specimens collected from each patient were tested for viral antibodies. The mean interval between the two specimens was 41 months. For those who developed antibody to rubella between these two blood specimens, all serial bloods which had been collected were then tested for rubella antibody. The history of rubella or rubella vaccine administration was confirmed by physicians' records. Each patient was matched by age, sex, and year of serum collection with serum stored in the clinical virology laboratory. The controls were from the Cincinnati metropolitan area and included both healthy children and those with a variety of diseases other than connective tissue diseases.

\section{SEROLOGICAL TECHNIQUES}

Serum specimens from patients and controls were tested simultaneously and in duplicate for rubella and rubeola haemagglutination inhibition (HI) antibody in a microtitre system (Sever, 1962). Rubella HI antibody was measured after pretreatment of the serum by the dextransulphate-calcium chloride method for removal of nonspecific inhibitors (Nelson, Quirin, and Inhorn, 1972). Measles HI antibody was measured using a Tween/ether treated measles haemagglutination antigen (provided by the Center for Disease Control, Atlanta, Georgia). The initial serum dilutions in all tests were $1: 8$, and the antibody titres are expressed as the reciprocal of the highest dilution giving complete inhibition of haemagglutination. In determining geometric mean titres (GMT), titres $<8$ were assumed to be 4 for the purpose of calculation.

IMMUNOGLOBULIN G LEVELS

Serum IgG levels were determined by radial immunodiffusion (Hyland Laboratories, Inc., Costa Mesa, Calif.) (Mancini, Carbonara, and Heremans, 1965).

\section{STATISTICAL TESTS}

Standard statistical tests were used (Snedecor and Cochran, 1967). Differences in antibody titre between study patierits and controls were compared by a ' $t$ ' test based on the logarithm of the dilution level and by a Wilcoxon-Mann Whitney rank test. Differences in proportions were tested for significance by the $\chi^{2}$ test. Correlation between antibody titres and IgG levels were measured after conversion to logarithms by the usual product moment correlation.

\section{Results}

Thirty-five of the patients with JRA were susceptible to rubella (HI titre $<8$ ) (Table I). The percentage of patients with antibody increased with age, from $11 \%$ of those aged 1 to 4 years to $100 \%$ of those 17 years or older. The GMT of rubella antibody also increased with age, and the maximum titres occurred in the 9to 12 -year-old group. In contrast to rubella, $90 \%$ of the patients had rubeola antibody, with an increase in the percentage with antibody from $38 \%$ in those aged 1 to 4 years to $96 \%$ in the 9- to 12 -year-old group.

When the GMT of rubella antibody of the study group was compared to the control group, there was no significant difference (Table II). However, if only JRA patients and control patients with rubella antibody were selected from the total group to correct for variations in exposure to rubella, the GMT for those with JRA was significantly greater than for controls. The same difference persisted if only the pairs of patients and controls in which both had rubella antibody were compared. This was significant ( $\mathrm{P}<0.05$ by both the ' $\mathrm{t}$ ' test and rank test). There was no significant difference in rubeola antibody between the groups.

The level of rubella antibody was evaluated in relation to the serum IgG levels, age at onset, type of onset, functional status, presence of rheumatoid factor or antinuclear antibody, and duration of rheumatoid disease. Quantitative IgG levels were measured by radial immunodiffusion, and there was a correlation between rubella $\mathrm{HI}$ titres and serum IgG $(r=0.34 ; P<0.05)$. In contrast to rubella, there was no correlation between rubeola $\mathrm{HI}$ titre and serum IgG $(r=0.14 ; \mathrm{P}>0.05)$. The GMT of rubella antibody was slightly higher for those who were older at the time of onset of JRA ( $45 \cdot 2$ for those with HI antibody $<5$ years old at the onset, compared to 63.4 for $>11$ years). The GMT was also higher for children with rubella antibody who were in functional class III compared to those in class I (76.1 against 58.9). There was no difference in GMT of rubella antibody between children as classified by the onset of disease (acute febrile, pauciarticular, or poly-

Table I Rubella HI antibody titres in JRA related to age

\begin{tabular}{|c|c|c|c|c|c|c|}
\hline \multirow{3}{*}{ Age at time of study (years) } & \multicolumn{4}{|c|}{ Rubella HI antibody } & \multicolumn{2}{|c|}{$G M T^{*}$ of rubella antibody } \\
\hline & \multicolumn{2}{|l|}{$<8$} & \multicolumn{2}{|l|}{$\geqslant 8$} & \multirow[t]{2}{*}{ All patients } & \multirow{2}{*}{$\begin{array}{l}\text { Patients with } H I \\
\geqslant 8\end{array}$} \\
\hline & No. & $\%$ & No. & $\%$ & & \\
\hline $\begin{array}{c}1-4 \\
5-8 \\
9-12 \\
13-16 \\
\geqslant 17\end{array}$ & $\begin{array}{r}8 \\
11 \\
11 \\
5 \\
0\end{array}$ & $\begin{array}{r}89 \\
61 \\
41 \\
19 \\
0\end{array}$ & $\begin{array}{r}1 \\
7 \\
16 \\
21 \\
5\end{array}$ & $\begin{array}{r}11 \\
39 \\
59 \\
81 \\
100\end{array}$ & $\begin{array}{r}4 \cdot 3 \\
11 \cdot 8 \\
23 \cdot 5 \\
32 \cdot 9 \\
42 \cdot 2\end{array}$ & $\begin{array}{r}8 \cdot 0 \\
64 \cdot 0 \\
79 \cdot 4 \\
54 \cdot 2 \\
42 \cdot 2\end{array}$ \\
\hline
\end{tabular}

*GMT = geometric mean titre. 
Table II Comparison of geometric mean titres of rubella and rubeola HI antibody in JRA and matched controls

\begin{tabular}{|c|c|c|c|}
\hline & $\begin{array}{l}\text { All patients, with or } \\
\text { without HI antibody }\end{array}$ & $\begin{array}{l}\text { All patients with } H I \\
\text { antibody } \geqslant 8\end{array}$ & $\begin{array}{l}\text { JRA and controls only, } \\
\text { both with HI antibody }\end{array}$ \\
\hline $\begin{array}{c}\text { Rubella } \\
\text { Patients } \\
\text { Controls } \\
\text { Rubeola }\end{array}$ & $\begin{array}{l}19 \cdot 5 \\
24.5\end{array}$ & $\left.\begin{array}{l}58 \cdot 9 \\
42 \cdot 7\end{array}\right\} P<0.05$ & $\left.\begin{array}{l}57 \cdot 7 \\
38 \cdot 1\end{array}\right\} P<0.05$ \\
\hline $\begin{array}{l}\text { Kuboola } \\
\text { Patients } \\
\text { Controls }\end{array}$ & $\begin{array}{l}35 \cdot 1 \\
37 \cdot 8\end{array}$ & $\begin{array}{l}45 \cdot 7 \\
45 \cdot 6\end{array}$ & $\begin{array}{l}45 \cdot 7 \\
46 \cdot 2\end{array}$ \\
\hline
\end{tabular}

Table III Response to rubella vaccine or natural infection in juvenile rheumatoid arthritis

\begin{tabular}{|c|c|c|}
\hline Case no. & Prerubella titre & Postrubella titre \\
\hline $\begin{array}{l}\text { Vaccinated } \\
1^{*} \\
2 \\
3 \\
4 \\
5 \\
6 \\
7 \\
8 \\
9 \\
10^{*} \\
11 \\
12\end{array}$ & $\begin{array}{l}<8 \\
<8 \\
<8 \\
<8 \\
<8 \\
<8 \\
<8 \\
<8 \\
<8 \\
<8 \\
<8 \\
<8\end{array}$ & $\begin{array}{l}16 \\
32 \\
32 \\
16 \\
16 \\
64 \\
16 \\
64 \\
16 \\
16 \\
16 \\
32\end{array}$ \\
\hline $\begin{array}{l}\text { Natural rub } \\
13 \\
14 \\
15\end{array}$ & $\begin{array}{l}\text { ella or unknown } \\
<8 \\
<8 \\
<8\end{array}$ & $\begin{array}{r}64 \\
128 \\
256\end{array}$ \\
\hline
\end{tabular}

* Had a mild exacerbration of symptoms within $8 \mathrm{w}$ of receiving rubella.

articular). Nineteen of 83 JRA patients tested had rheumatoid factor in initial serum specimens, and 20 of 78 had antinuclear antibody. There was no correlation between the presence or absence of rheumatoid factor or antinuclear antibody and the level of rubella antibody. The level of antibody did not vary consistently with the duration of illness.

When the second serum specimen from each patient was tested for rubella antibody, the GMT for those with rubella antibody was $51 \cdot 2$, compared to 58.9 on the initial test. Fifteen of the 35 children with HI titres $<8$ had developed rubella antibody in the interval between the collection of two blood specimens (Table III). Serial blood specimens were tested for each of the 15 children to define the time of seroconversion. Twelve of the 15 had received rubella vaccine which resulted in $\mathrm{HI}$ titres ranging from 16 to 64 with a GMT of 24 . Of the other three children, one had a clinical history of rubella, one had not received vaccine and did not have a history of clinical disease, and a history was unavailable on the third. The GMT for this group was 128 . Two children had mild exacer- bations of their disease within 8 weeks of receiving the vaccine. Serum IgG levels were measured in 14 pairs of blood samples in which there was a rise in rubella HI antibody. Four children had a rise in IgG, three had a decrease, and seven had no change.

In serial bloods from three children, there were fourfold changes in rubella $\mathrm{HI}$ titres after the initial seroconversion. One child seroconverted after rubella vaccine and then had 5 successive fourfold changes in antibody titre associated with changes in serum IgG (Figure). Rubeola antibody did not show parallel changes. A second child developed a fourfold rise and fall in rubella $\mathrm{HI}$ titres unrelated to documented natural rubella or rubella vaccine, and subse quently showed a fourfold rise in HI antibody aftes receiving rubella vaccine. The serum with the initias rise in rubella $\mathrm{HI}$ antibody did not contain rubello neutralizing antibody and was shown to have $\vec{a}$ similar rise in rubeola $\mathrm{HI}$ antibody. Therefore, it probably represented a nonspecific haemagglutination inhibitor. A third child, who seroconverted after rubella vaccine, had an $\mathrm{HI}$ titre of 16 to 32 which persisisted for one to two years and then decreased to 8. This was associated with a decrease in serum IgG of greater than $5 \mathrm{~g} / 1(500 \mathrm{mg} / 100 \mathrm{ml})$ and there was also a fourfold decrease in rubeola antibody at the same time.

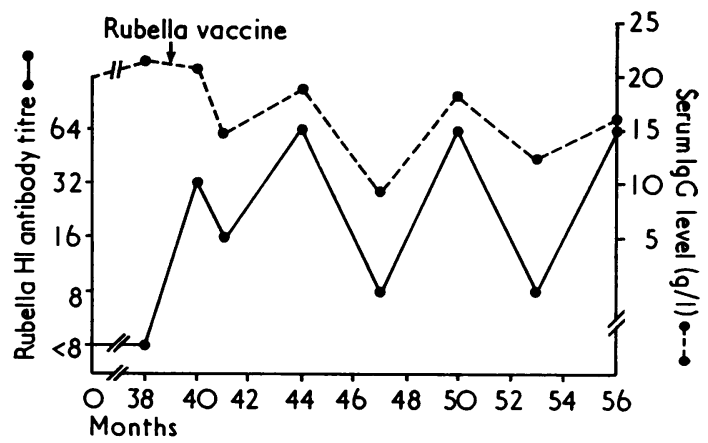

FIGURE Serial rubella HI antibody titres and serum IgG levels in a child with juvenile rheumatoid arthritis, who received rubella vaccine, by month since the onset of disease 


\section{Discussion}

The present study found no difference in GMT of rubella HI antibody between those with JRA and age- and sex-matched controls if all subjects were considered (Table II). However, if only those definitely infected with rubella virus (HI titre $\geqslant 8$ ) were considered, a slight but significant increase in rubella antibody level was found in the JRA group. The differences in the antibody titres between the present study and that of Ogra and Herd (1972) may simply reflect differences in experience with rubella virus in the study areas. There are several possible explanations for the increased level of rubella antibody. (1) Rubella virus may cause JRA. (2) The patient with JRA may have an unusual response to primary infection with rubella virus. (3) The increase in rubella antibody reflects a nonspecific increase in serum immunoglobulins. Or (4) once infected with rubella virus, there is a persistent infection.

The present study seems to exclude the first two possibilities. The percentage of children with JRA who had rubella antibody and the distribution of antibody by age groups was similar to that which has been reported in normal subjects (Witte, Karchmer, Case, Herrmann, Abrutyn, Kassanoff, and Neill, 1969). The fact that 35 of 85 children $(41 \%)$ with JRA lacked rubella antibody and responded normally to challenge with rubella virus suggests that this virus was not the causal agent in this disease, unless there are several aetiologies for the same clinical syndrome. Rubella infection did not result in unusually high antibody titres and in only two patients was there any exacerbation of clinical symptoms. This suggests that an unusual host response to primary infection is not the explanation for the increase in rubella antibody levels.

The most likely explanation seems to be that the increased rubella antibody reflects a general increase in serum immunoglobulins. The extensive studies of Phillips and Christian $(1972,1973)$ on viral antibodies in connective tissue diseases support this interpretation, as does the present study. They have shown a correlation between serum gammaglobulins and IgG with a variety of viral antibodies. Raised serum immunoglobulins occurs in JRA, but much less frequently than in SLE (Bluestone, Goldberg, Katz, Marchesano, and Calabro, 1970). This may explain the difference in degree of rise in antibodies between the two diseases. The variation among antibodies to different viruses is more difficult to explain. In the present study, rubella antibody was increased and rubeola antibody was not. The interval since exposure to a virus may be important. Experience with rubeola for most of the patients in this study would be a result either of natural disease in the mid 1960s or from vaccine, which has been available since 1963. Natural disease has not recurred in the study area until 1971, after the initial blood specimen had been drawn from all but one of the study patients. In contrast to rubeola, rubella occurs every year. Also, rubella vaccine did not become available until 1969 and was not used extensively until 1970 . Therefore, rubella infection either by disease or vaccine probably occurred more recently than rubeola. Subclinical rubella reinfection is common after vaccination and could account for a persistent rise in antibody levels (Horstmann, Liebhaber, Le Bouvier, Rosenberg, and Halstead, 1970).

An unresolved question is whether or not there is persistent rubella virus infection in JRA. Infection with rubella virus often causes arthralgias and arthritis, which may result from direct invasion of the joint by the virus (Yanez, Thompson, Mikkelsen, and Bartholomew, 1966). Experimental rubella infection in rabbits has shown the highest titres of virus in the chondrocytes and rubella virus has been recovered from the synovial fluid of children with recurrent arthritis after rubella vaccine, 3 to 4 months after vaccination (London, Fuccillo, Anderson, and Sever, 1970; Ogra and Herd, 1971). Ogra and Herd (1972) have reported the presence of rubella antigen in the synovial fluid of two JRA patients as detected by immunofluorescent staining, but they did not grow the virus. The fluctuations in rubella antibody titres seen in the patient illustrated in the Figure could reflect exacerbation of a persistent infection with increased viral replication and antibody production. However, careful attempts to culture the virus by a variety of techniques have been unsuccessful (Phillips, 1971).

We wish to thank Dr. Evelyn Hess for reviewing the manuscript, and Mary Jane Heimbrock and Tom Rotte for their technical assistance. Supported in part by the Ohio Valley Chapter of the Arthritis Foundation, and Career Development Award 5 KO3 HD13566.

\section{References}

Adams, J. M. (1967) Neurology, 17, 707 (Measles antibodies in patients with multiple sclerosis)

Bluestone, R., Goldberg, L. S., Katz, R. M., Marchesano, J. M., and Calabro, J. J. (1970) J. Pediat., 77, 98 (Juvenile rheumatoid arthritis: a serologic survey of 200 consecutive patients)

Brewer, E. J., Bass, J. C., Cassidy, J. T., Duran, B. S., Fink, C. W., Jacobs, J. C., Markowitz, M., Reynolds, W. E., Schaller, J., Stillman, J. S., AND Wallace, S. L. (1972) Bull. Rheum. Dis., 23, 712 (Criteria for the classification of juvenile rheumatoid arthritis)

Connolly, J. H., Allen, I. V., Hurwitz, L. J., AND Millar, J. H. D. (1967) Lancet, 1, 542 (Measles-virus antibody and antigen in subacute sclerosing panencephalitis) 
Horstmann, D. M., Liebhaber, H., Le Bouvier, G. L., Rosenberg, D. A., and Halstead, S. B. (1970) New Engl. J. Med., 283, 771 (Rubella: reinfection of vaccinated and naturally immune persons exposed in an epidemic)

London, W. T., Fuccillo, D. A., ANDerson, B., AND Sever, J. L. (1970) Nature, 226, 172 (Concentration of rubella virus antigen in chondrocytes of congenitally infected rabbits)

Mancini, G., Carbonara, A. O., and Heremans, J. F. (1965) Immunochemistry, 2, 235 (Immunochemical quantitation of antigens by single radial immunodiffusion)

Nelson, D. B., Quirin, E. P., AND InHORN, S. L. (1972) Appl. Microbiol., 24, 264 (Improved dextran sulfate-calcium chloride method for the removal of nonspecific inhibitors with modifications for nonspecific agglutinin removal in the rubella hemagglutination inhibition test)

OGRA, P. L., AND HERD, J. K. (1971) J. Immunol., 107, 810 (Arthritis associated with induced rubella infection)

- (1972) Arthr. and Rheum., 15, 121 (Abstr.) (Serologic association of rubella virus infection and juvenile rheumatoid arthritis (JRA))

Phillips, P. E. (1971) J. exp. Med., 134, 313S (Virologic studies in rheumatoid arthritis and other connective tissue diseases)

—, AND Christian, C. L. (1970) Science, 168, 982 (Myxovirus antibody increases in human connective tissue disease)

- _- (1972) Proc. Soc. exp. Biol. (N.Y.), 140, 1340 (The influence of serum immunoglobulin concentration on measles antibody level)

—- (1973) Ann. Rheum. Dis., 32, 450 (Virus antibodies in systemic lupus erythematosus and other connective tissue diseases)

- Lim, W., Parkman, P., and Hirshaut, Y. (1973) Arthr. and Rheum., 16, 126 (Abstr.) (Virus antibody and IgG levels in juvenile rheumatoid arthritis (JRA))

SEVER, J. L. (1962) J. Immunol., 88, 320 (Application of a microtechnique to viral serological investigations)

SNEDECOR, G. W., AND Cochran, W. G. (1967) In 'Statistical Methods', 6th edition. Ames, Iowa State University Press, Iowa

Witte, J. J., Karchmer, A. W., Case, G., Herrmann, K. L., Abrutyn, E., Kassanoff, I., and Neill, J. S. (1969) Amer.J. Dis. Child., 118, 107 (Epidemiology of rubella)

Yanez, J. E., Thompson, G. R., Miknelsen, W. M., and Bartholomew, L. W. (1966) Ann. intern. Med., 64, 772 (Rubella arthritis) 